\title{
Total Intra Venous Anesthesia (TIVA) Target Controlled Infusion (TCI) Propofol Remifentanil untuk Seksio Sesarea Emergensi pada Pasien Meningioma dengan Peningkatan Tekanan Intrakranial
}

\author{
Tjahya Aryasa*), Ratih Kumala Fajar Apsari**), Sri Rahardjo $\left.{ }^{* *}\right)$ \\ *Departemen Anestesiologi dan Reanimasi Fakultas Kedokteran Universitas Udayana-RSUP Sanglah Denpasar \\ Bali, ${ }^{* *}$ Departemen Anestesiologi dan Terapi Intensif Fakultas Kedokteran Kesehatan Masyarakat dan Keperawatan \\ Universitas Gajah Mada
}

\begin{abstract}
Abstrak
Meningioma sangat jarang ditemukan pada kehamilan, tapi kehamilan dapat memicu pertumbuhan meningioma. Ibu hamil yang menjalani seksio sesarea dengan penyulit tumor otak merupakan indikasi anestesi umum dengan kombinasi Target Controlled Infusion (TCI) propofol dan remifentanil. Propofol pada seksio sesarea dapat mengatasi respons simpatis akibat laringoskopi. Remifentanil berhubungan dengan hasil luaran lebih baik pada neonatus dari opioid lainnya. Perempuan 34 tahun, hamil 37 minggu datang dengan keluhan utama nyeri perut hilang timbul disertai kebutaan dan tanda peningkatan tekanan intrakranial tanpa penurunan kesadaran. Tidak dilakukan CT-Scan kepala karena direncanakan seksio sesarea emergensi. Dilakukan seksio sesarea dengan teknik anestesi umum menggunakan TCI propofol mode Marsh dengan target efek 3-4 mcg/ml dan TCI remifentanil dengan target 2-3 ng/ml, dan rocuronium dengan dosis $0,7 \mathrm{mg} / \mathrm{kgBB}$. Pada menit kesepuluh, lahir bayi lakilaki, dengan berat badan 2000 gram dan skor APGAR 7-8. Selama operasi hemodinamik stabil dan tidak ada komplikasi. pascabedah dilakukaan pemeriksaan CT-scan dan ditemukan meningioma yang besar. Teknik ini memberikan hasil luaran pada neonatal dan ibu yang baik.
\end{abstract}

Kata kunci: Ibu hamil; meningioma; peningkatan tekanan intrakranial; propofol; remifentanil

JNI 2020; 9 (1): 26-32

\section{Total Intra Venous Anethesia (TIVA) Target Controlled Infusion (TCI) with Propofol Remifentanil for Emergency Caesarean Section in Meningioma Patient with Increase Intracranial Pressure}

\begin{abstract}
Meningiomas are very rare in pregnancy, but pregnancy triggers the growth of meningiomas. Pregnant women who undergo cesarean section complicated with brain tumor are an indication of general anesthesia with Target Controlled Infusion (TCI) propofol and remifentanil. Propofol can blunt sympathetic response due to laryngoscopy. Remifentanil has a better outcomes in neonates than other opioids. A 34-year-old woman, 37-weeks pregnant presented with uterine contractions accompanied with blindness and signs of increased intracranial pressure without decreased consciousness. Head CT scan was not performed because an emergency cesarean section was planned. Caesarean section was performed with general anesthesia using Target Controlled Infusion (TCI) Marsh mode propofol with a target effect of 3-4 $\mathrm{mcg} / \mathrm{ml}$ and remifentanil TCI with a target of 2-3 ng/ml, and rocuronium $0.7 \mathrm{mg} / \mathrm{kg}$. At the tenth minute, a male baby was born, weighing 2000 grams and an APGAR score of 7-8. During surgery, the hemodynamic was stable without complications. Postoperatively, a CT scan was performed and a large meningioma was found. This technique provided good neonatal and maternal outcome outcomes.
\end{abstract}

Key words: Pregnancy; meningioma; increased intracranial pressure; propofol; remifentanil

JNI 2020; 9 (1): 26-32 


\section{Pendahuluan}

Teknik anestesi yang paling umum dilakukan untuk seksio sesarea adalah teknik anestesi regional. Namun, pada beberapa kondisi diperlukan pemilihan teknik anestesi umum, seperti adanya riwayat operasi pada bagian punggung, gagalnya blok regional, persalinan yang harus segera dilakukan, dan pada koagulopati maternal. Anestesi umum sering pula digunakan pada pasien hamil dengan status fisik ASA III dan IV dengan adanya penyakit neurologis dan penyakit jantung. ${ }^{1,2}$

Pada jaman dahulu, agen anestesi umum yang sering digunakan untuk induksi pada pasien hamil yang menjalani seksio sesarea adalah thiopental dan suksinilkolin dan anestesi dipertahankan dengan menggunakan nitrous oxide dan agen inhalasi dengan konsentrasi rendah. ${ }^{1,3}$ Kelemahan dengan menggunakan metode ini adalah cepat kembalinya kesadaran ibu saat operasi (awareness), analgesia yang tidak adekuat, dan munculnya respons hipertensi pada saat laringoskopi, intubasi trakeal, dan insisi. Hal ini dapat diminimalisir dengan penggunaan opioid, seperti alfentanil dan fentanil, namun opioid jenis ini dapat menyebabkan kondisi nilai Apgar fetus menurun dan terjadinya depresi napas sehingga janin perlu dilakukan tindakan intubasi. Hal lain yang juga menjadi perhatian adalah adanya akumulasi opioid pada air susu ibu. ${ }^{1,3,4,5}$ Meningioma sangat jarang ditemukan wanita muda dan bahkan lebih jarang dalam kehamilan, akan tetapi kehamilan dapat memicu pertumbuhan meningioma dan gejalanya dapat semakin terlihat selama kehamilan karena retensi air dan bendungan pembuluh darah. Adanya reseptor hormon seks pada sel tumor menyebabkan pertumbuhan tumor yang cepat. ${ }^{6,7}$

Meningioma ditemukan secara kebetulan atau dengan gejala yang tidak spesifik. Sekitar seperempat dari semua meningioma yang didiagnosis akhirnya membutuhkan perawatan. Delapan puluh persen dari pasien adalah wanita. Gejala klinis yang khas adalah hilangnya ketajaman penglihatan, diplopia, gangguan lapang pandang, dan proptosis sekitar 10\%.
Selain hilangnya lapang pandang hingga kebutaan, keluhan yang sering dikeluhkan adalah nyeri kepala. Propofol adalah agen induksi intravena dengan kerja cepat, dan dapat menghasilkan induksi anestesi yang baik. Walaupun penggunaan propofol sebagai agen induksi untuk persalinan seksio sesarea masih diperdebatkan, propofol terbukti dapat mengatasi respons yang diakibatkan tindakan laringoskopi. ${ }^{8}$ Pada sebuah penelitian menyatakan bahwa penggunaan propofol menyebabkan skor Apgar yang lebih rendah dan skor neurobehavioural yang lebih rendah satu jam setelah persalinan, bila dibandingkan dengan thiopental. ${ }^{9}$ Sedangkan hasil tersebut tidak ditemukan pada beberapa penelitian yang dilakukan menggunakan propofol sebagai agen induksi pada persalinan seksio sesarea. Propofol akan melewati plasenta dengan cepat, namun akan dengan cepat juga diekskresikan dari sirkulasi neonatus. ${ }^{8-10}$

Saat ini terdapat satu agen opioid yaitu remifentanil yang memiliki karakteristik berupa waktu kerja yang singkat, sehingga dapat dipertimbangkan untuk mengatasi respons simpatis maternal, mengurangi tingkat kesadaran maternal saat operasi, dan analgesia yang lebih adekuat dengan regimen anestesi yang disebutkan di atas. Remifentanil memiliki waktu paruh sangat pendek pada individu yang tidak hamil, walaupun bila diberikan secara kontinyu. Remifentanil akan dimetabolisme dengan cepat oleh enzim esterase plasma non-spesifik, dan tidak bergantung dengan metabolisme organ. Remifentanil pada dosis $0,1 \mu \mathrm{g} / \mathrm{kg} /$ menit, akan secara cepat dan ekstensif melewati plasenta (rasio vena umbilikus/arteri maternal adalah sebesar $0,88) \cdot{ }^{11}$ Sebagai tambahan, rasio arteri umbilikus/ vena umbilikus adalah 0,29 , dimana hal ini memiliki makna bahwa terjadi metabolisme dan/ atau redistribusi fetal yang cepat.

Pada laporan ini, kami akan menguraikan sebuah laporan kasus dimana seorang wanita hamil yang memiliki penyulit saat masuk rumah sakit berupa tumor otak disertai tanda-tanda peningkatan tekanan intrakranial tapi akan dilakukan tindakan seksio sesarea emergensi sehingga dipilih teknik anestesi umum. Kami memilih menggunakan 
remifentanil dan propofol sebagai agen induksi, dan pada laporan kasus ini akan dijabarkan hasil luaran yang disebabkan oleh kedua agen tersebut, baik hasil luaran maternal maupun neonatal.

\section{Kasus}

\section{Anamnesis}

Seorang perempuan 34 tahun, kehamilan keempat dengan riwayat tiga persalinan normal aterm sebelumnya, ketiga anaknya masih hidup, saat ini hamil dengan umur kehamilan 37 minggu datang dengan keluhan nyeri perut hilang timbul disertai juga dengan keluhan nyeri kepala, disertai kebutaan pada kedua mata, muntah proyektil tanpa disertai dengan penurunan kesadaran. Keluhan nyeri kepala ini sudah dirasakan sejak 3 bulan terakhir dan memberat dalam 1 bulan terakhir. Keluhan penurunan fungsi penglihatan sejak 1 bulan terakhir dan sejak 1 minggu terakhir pasien mengaku tidak dapat melihat cahaya sama sekali. Keluhan penurunan fungsi penglihatan diawali dengan diplopia yang memberat seiring waktu hingga tidak dapat melihat cahaya sama sekali. Pada trimester pertama dan kedua tidak ada keluhan dan gangguan klinis yang berarti. Pada riwayat kehamilan sebelumnya maupun riwayat keluarga tidak ditemukan adanya kejadian serupa.

\section{Pemeriksaan Fisik}

Pemeriksaan fisik pada pasien ini menunjukkan pasien dalam keadaan sadar penuh dengan skor Glasgow Coma Scale (GCS) 15. Nadi 67 kali/ menit, tekanan darah 110/70 mmHg. Tidak didapatkan tanda-tanda anemis dan febris. Pada pemeriksaan neurologis, ditemukan visus no light perception pada kedua mata. Tidak ditemukan defisit pada nervus kranialis lainnya. Tidak ditemukan kelainan pada sistem kardiovaskular dan respirasi. Pada pemeriksaan abdomen, ditemukan ukuran uteri setara dengan 36 minggu, dengan presentasi kepala dan denyut jantung janin $118 \mathrm{kali} / \mathrm{menit}$. Pada pemeriksaan USG Obstetrik di temukan janin tunggal, sefalik, 36 minggu gestasi, dengan Amniotic Fluid Index (AFI) $8 \mathrm{~cm}$.
Pemeriksaan Penunjang

Pada pemeriksaan laboratorium didapatkan:

WBC $11,06 \times 103 / \mu \mathrm{L} \quad$ aPTT 29,7

HGB $11,63 \mathrm{~g} / \mathrm{dL}$

SGOT 28,1 U/L

HCT $32,77 \%$

Albumin 3,70 gr/dL

PLT $248,50 \times 103 \mu \mathrm{L}$

BUN $15,00 \mathrm{mg} / \mathrm{dL}$

PT 13,4 detik

INR 0,96

$\mathrm{SC} 1,11 \mathrm{mg} / \mathrm{dL}$

$\mathrm{Na} 137 \mathrm{mmol} / \mathrm{L}$

$\mathrm{K} 4.07 \mathrm{mmol} / \mathrm{L}$

$\mathrm{Cl} 106 \mathrm{mmol} / \mathrm{L}$

WBC, white blood cell; HGB, haemoglobin; HCT, henatokrit; PLT,palatelet;PT, protrombine time;INR international normalized ratio; K,kalium;CL,clorida; aPTT, activated partial tromboplastin time; SGOT serum glutamic oxaloacetic transaminase; BUN binding ureum nitrogen;SC, serum creatinin; $\mathrm{Na}$, natrium;

\section{Pengelolaan Anestesi}

Pasien dilakukan operasi dengan anestesi umum dengan Target Controlled Infusion (TCI) propofol dengan mode Marsh dengan target efek 3-4 $\mathrm{mcg} / \mathrm{ml}$ dan remifentanil dengan target 2-3 $\mathrm{ng} / \mathrm{ml}$, pelumpuh otot menggunakan rocuronium dengan dosis 0,7 mg/kgBB. Pada menit kesepuluh lahir bayi laki-laki, dengan berat 2000 gram dengan skor APGAR 7-8. Selama operasi kondisi hemodinamik stabil dan tidak ditemukan komplikasi. Tekanan darah dipertahankan dengan MAP berkisar 70-80 mmHg, nadi 70-80 kali permenit, saturasi oksigen 89-99\%, dengan end tidal $\mathrm{CO}_{2}$ berkisar $28-35 \mathrm{mmHg}$. Oleh karena operasi bersifat emergensi, maka tidak dilakukan pemeriksaan CT-Scan. Pemeriksaan penunjang CT-Scan akan direncanakan setelah operasi selesai.

HemodinamikSelama Operasi

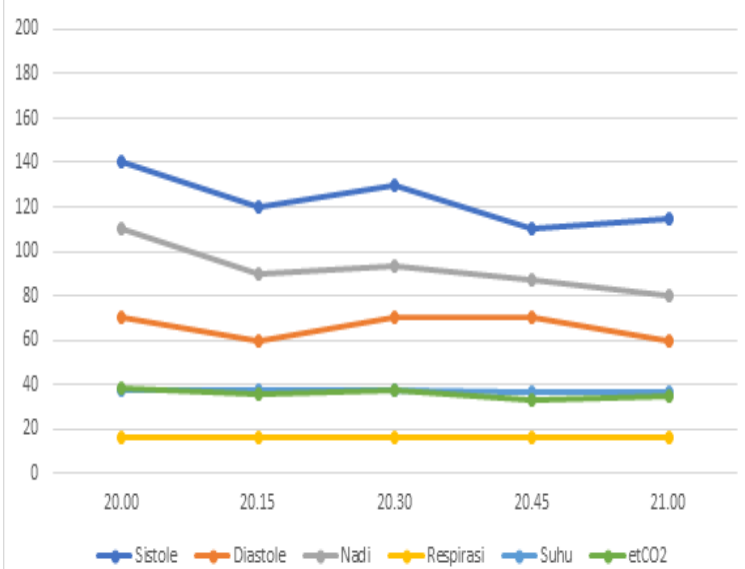



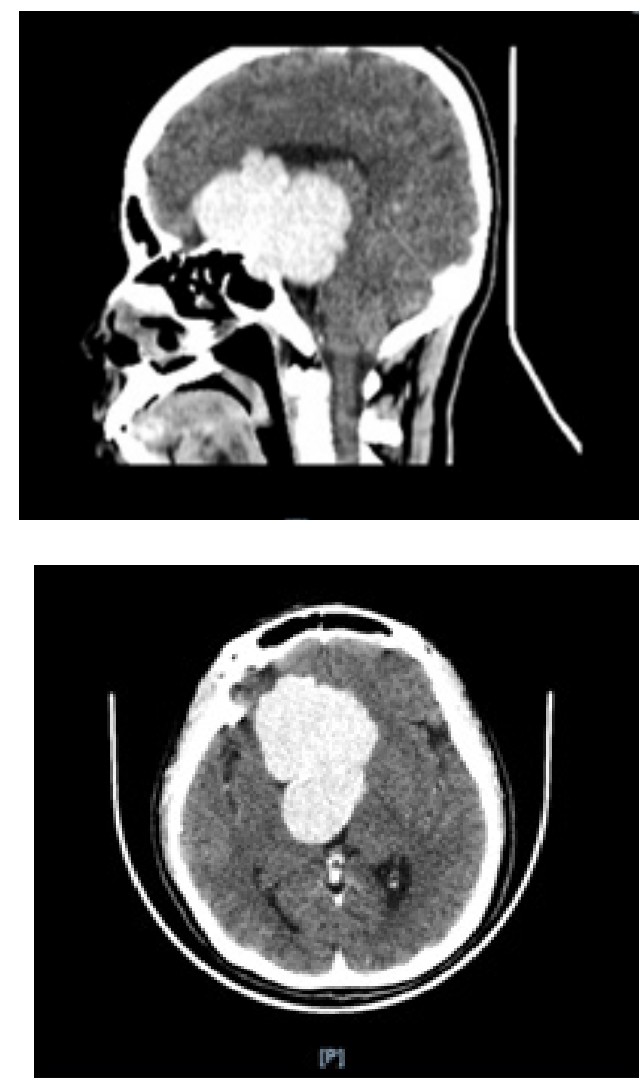
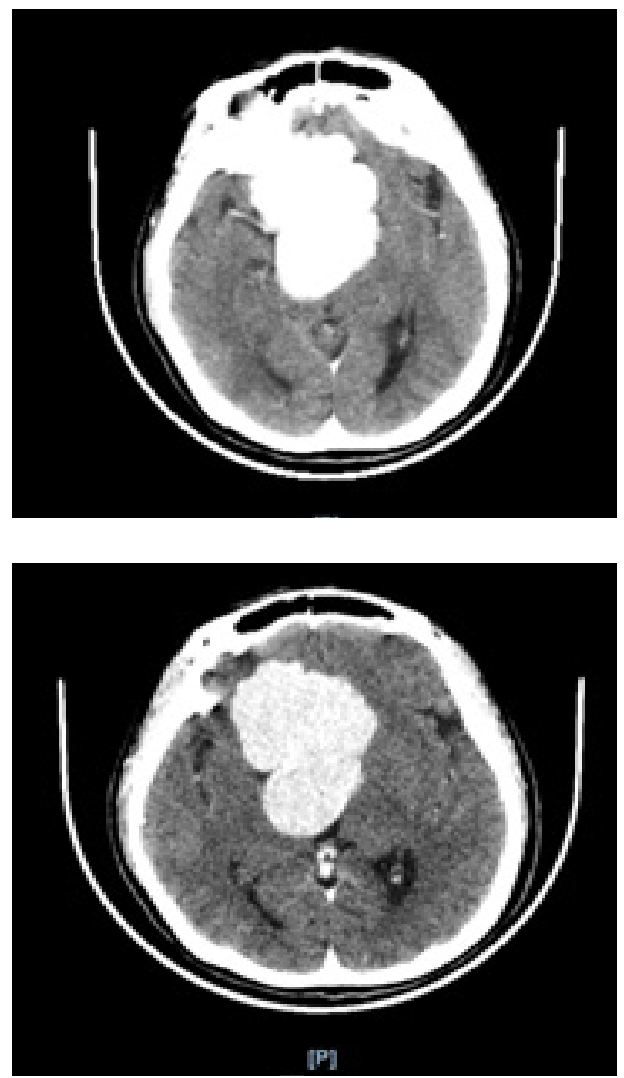

Gambar1. CT Scan Kepala Post Operasi

\section{Pengelolaan Pascabedah}

Setelah pasien menjalani operasi seksio sesarea, pasien dirawat diruang intensif untuk dilakukan observasi ketat pascabedah. Hemodinamik stabil dengan nyeri operasi minimal, dengan Numeric Rating Scale 2/10. Pascabedah hari pertama dilakukan $\mathrm{CT}$ scan dan didapatkan hasil massa ekstraaksial dengan ukuran $7,1 \mathrm{~cm}$ x $5,1 \mathrm{~cm}$ $\mathrm{x} 4,3 \mathrm{~cm}$ pada intrasella yang meluas hingga suprasella, yang menekan chiasma opticus, mendesak midbrain, pons, ventrikel lateralis kanan, dan ventrikel III, yang menyebabkan midline shift ke kiri dan non communicating hydrocephalus, sesuai gambaran primary brain tumor dengan diagnosis banding meningioma suprasella. Pasien dikosulkan ke sejawat bedah saraf dengan kesimpulan hasil konsul pasien akan dirawat poliklinis dan direncanakan pasien akan dipulangkan terlebih dahulu, kemudian pasien direncanakan untuk operasi elektif tumor otak oleh sejawat bedah saraf.

Oleh karena keluhan nyeri kepala sudah berkurang setelah operasi seksio sesarea pasien tidak mendapatkan terapi medikamentosa dari sejawat bedah saraf.

\section{Pembahasan}

Pada kasus kehamilan dengan komplikasi tumor otak, strategi tatalaksana bersifat individual. Pembedahan tumor selama kehamilan jarang dibutuhkan. Intervensi segera untuk tumor otak pada kehamilan dilakukan apabila ditemukan tanda: (1) keganasan, (2) hidrosefalus aktif, (3) tumor jinak (seperti meningioma) yang menunjukkan adanya tanda-tanda herniasi maupun defisit neurologis yang progresif., ${ }^{2,3}$ Sebagian besar kehamilan dapat dilanjutkan sampai usia kehamilan aterm dengan pemantauan pertumbuhan janin dan volume cairan, dengan atau tanpa Dopplers, dan pemantauan neurologis maternal secara ketat.Persalinan pervaginam dapat dilakukan, namun seksio sesarea diindikasikan jika ada peningkatan tekanan intrakranial atau kegawatan di bidang kebidanan. ${ }^{4}$ Peningkatan 
tekanan intrakranial merupakan salah satu kontra indikasi dilakukannya anestesi regional, Untuk menghindari peningkatan tekanan intracranial pada pasien ini dipilih dilakukan general anestesi TIVA dengan menggunakan medikasi propofol dan remifentanil karena kedua obat tersebut baik dan aman diggunakan pada operasi seksio sesarea pada ibu hamil disertai dengan peningkatan tekanan intrakranial yang disebabkan oleh meningioma. Dengan general anestesi seorang anestesi lebih dapat mengendalikan tekanan intrakranial pada pasien dengan peningkatan tekanan intrakranial. Propofol dan remifentanil infus kontinyu dengan menggunakan alat TCI dapat menjaga kestabilan hemodinamik selama proses pembedahan dan memiliki efek yang menimal pada janin. ${ }^{1}$ Propofol yang dikombinasikan dengan remfentanil dapat menumpulkan respons stress maternal dan dapat menjaga stabilitas hemodinamik. Lebih lanjut lagi, dengan teknik induksi dan pemeliharaan anestesi saat ini, tampaknya penggunaan kedua agen tersebut cukup aman untuk neonatus. Namun, harus ditekankan bahwa hasil ini berlaku pada kondisi neonatus yang tidak menunjukkan tanda-tanda kegawatan janin akut sebelum induksi anestesi. ${ }^{1}$

Propofol diketahui dapat melewati sawar plasenta, baik sebagai agen induksi dan sebagai agen pemeliharaan anestesi. Namun, propofol diketahui dapat dengan cepat hilang dari sirkulasi neonatal dan sulit untuk dideteksi di kolostrum dan air susu ibu. Telah dibuktikan bahwa penggunaan propofol dapat mengatasi respons hipertensi akibat proses laringoskopi, intubasi, dan insisi. Propofol banyak dihubungkan dengan komplikasi berupa bradikardia maternal yang berat saat proses induksi anestesi umum pada pasien wanita muda sehat dan terutama pada pasien hamil. ${ }^{1,2,4}$ Hal ini paling nyata apabila propofol diberikan bersama dengan suksinilkolin. Propofol dapat menyebabkan efek simpatolisis dan muskarinik yang berlebihan akibat pemberian suksinilkolin, dan akhirnya menyebabkan bradikardia.

Pemberian propofol secara bolus dengan dosis tinggi $(>2,5 \mathrm{mg} / \mathrm{kg})$ dihubungkan dengan hasil luaran neonatal yang buruk. Namun, dengan pemberian propofol bolus $2 \mathrm{mg} / \mathrm{kg}$ terbukti tidak menyebabkan depresi pada hasil luaran neonatal, yang dibuktikan dengan penilaian menggunakan skor Apgar dan neurobehavioural. Penelitian yang telah dilakukan akhir-akhir ini menyatakan bahwa propofol aman digunakan pada operasi seksio sesaria dengan menggunakan target konsentrasi sedang. ${ }^{1}$ Penggunaan propofol sebagai agen induksi untuk operasi seksio sesaria sebenarnya belum mendapatkan rekomendasi resmi dari Food and Drug Administration (FDA), serta European Union. ${ }^{1}$ Namun dari praktik dan penelitian akhir-akhir ini menyatakan bahwa tidak ditemukan adanya efek ireversibel atau efek yang memanjang pada neonatus akibat penggunaan propofol. Oleh karena itu, penggunaan propofol harus dilakukan dengan bijaksana dan dengan penuh kewaspadaan. ${ }^{2,11,8}$

Keamanan penggunaan remifentanil terhadap hasil luaran neonatus telah diinvestigasi pada beberapa penelitian, dan mempertimbangkan bahwa remifentanil dapat pula diberikan sebegai analgesia persalinan. Walaupun dengan menggunakan dosis yang lebih rendah, tidak pernah ditemukan adanya efek samping pada neonatus akibat penggunaan remifentanil. Pada beberapa penelitian, remifentanil akhirnya dihentikan pada persalinan kala dua. Remifentanil ditemukan memiliki farmakokinetik yang sama pada neonatus, anak, dan dewasa. ${ }^{2,5}$

Remifentanil memiliki keuntungan lebih untuk hasil luaran pada neonatus dari opioid lainnya, seperti alfentanil dan fentanil. Baik alfentanil dan fentanil telah sering digunakan sebagai agen untuk anestesi umum pada operasi seksio sesaria dan penggunaan keduanya menyebabkan pemanjangan depresi napas neonatal dan rendahnya skor Apgar sehingga terkadang diperlukan untuk memberikan nalokson dan intubasi trakea. ${ }^{1,2}$ Pada kasus, kemungkinan adanya tumor otak didapatkan dari anamnesis dan pemeriksaan fisik. Gejala klinis yang disebabkan oleh tumor otak seperti nyeri kepala, muntah, dan kejang terkadang disalah artikan sebagai suatu kondisi hiperemesis gravidarum pada awal kehamilan atau dengan eklampsia pada akhir masa kehamilan. Namun hal ini dapat 
dibedakan dengan adanya temuan abnormal pada pemeriksaan funduskopi, gangguan penglihatan, kejang fokal, dan adanya defisit neurologis pada satu sisi. Kemudian dapat dilakukan pemeriksaan penunjang dengan pemeriksaan CT-scan (prosedur radiologi dilakukan dengan memberikan perlindungan pada daerah rahim) atau MRI. ${ }^{2,6}$ Pada kasus dilakukan operasi dengan teknik anestesi umum dengan TCI dengan mode Marsh dengan target efek 3-4 mcg/ml dan remifentanil 2-3 ng/ml. Tidak dilakukan bolus propofol dengan tujuan tidak mendepresi neonatus. Pada kasus, tekanan darah dapat dipertahankan dengan sistolik tertinggi $140 \mathrm{mmHg}$, MAP berkisar 70$80 \mathrm{mmHg}$. Tidak ada peningkatan nadi selama laringoskopi dengan nadi selama operasi berada dalam rentang 70-80 kali per menit. Pada menit ke sepuluh lahir bayi dengan skor APGAR 7-8. Penggunaan opioid pada operasi seksio sesarea dikhawatirkan menyebabkan depresi napas pada neonatus. Penggunaan remifentanil dengan TCI dosis 2-3 ng/ml pada kasus ditemukan tidak menyebabkan depresi napas pada neonatus. Penggunaan propofol juga berpotensi menghasilkan luaran neonatus yang buruk, tapi tidak terjadi pada kasus, diperkirakan karena digunakan teknik TCI mode Marsch tanpa dosis bolus yang tinggi.

Pasca bedah pasien dirawat di ruang intensif dan dilakukan observasi ketat. Nyeri pasca operasi minimal dengan Numeril Rating Scale 2/10 dan hemodinamik stabil. Tidak ditemukan perburukan tanda peningkatan intrakranial maupun defisit neurologis. Temuan meningioma suprasella pada CT scan pasca operasi menunjukkan bahwa keputusan untuk menggunakan anestesi umum pada kasus sudah tepat.

\section{Simpulan}

Ibu hamil yang menjalani operasi seksio sesarea emergensi dengan menggunakan teknik anestesi umum karena adanya penyulit berupa tumor otak dan peningkatan tekanan intrakranial maka pemilihan agen induksi berupa remifentanil yang dikombinasikan dengan propofol dapat memberikan hasil luaran maternal dan neonatal yang baik. Laporan kasus ini dapat menjadi gambaran dalam menghadapi kasus serupa pada praktek klinis sehari-hari. Masih diperlukan lebih banyak data dan penelitian lanjutan untuk meberikan panduan pelayanan yang lebih baik.

\section{Daftar Pustaka}

1. Jenkin JG, Khan MM. Anasethesia for caesarean section: a survey in a UK region from 1992 to 2002. Anaesthesia 2003;58:1114-8.

2. Van de Velde M, Teunkens A, Kuypers M, Dewinter T,Vandermeersch E. General anaesthesia with target controlled infusion of propofol for planned caesarean section: maternal and neonatal effect of a remifentanilbased technique. International Journal of Obstetric Anesthesia 2004;83:135-58.

3. Allen RW, James MFM, Uys PC.Attennuation of the pressor respon to tracheal intubation in hypertensive proteinuric pregnant patient bay lignocaine, alfentany and magnesium sulphate. Br J Anaesth 1991;66:216-23.

4. Steer PL, Biddle CJ, Marley WS, Lantz RK, Sulik PL. Concentration of fentanyl in colostrum after an analgesic dose. Can J Anaesth. 1992; 39: 231-5.

5. Kan RE, Hughes SC, Rosen MA, Kessin $C$, Preston PG, Lobo EP. Intravenous remifentanil: placental transfer, maternal and neonatal effects. Anesthesiology 1998; 88: 1467-74.

6. Kanaan I, Edin RCS, Jallu A. Management strategy for meningioma in pregnancy: a clinical study. Skull base: an interdisciplinary approach 2003;13(4):197-204.

7. Gin T, O'Meara ME, Kan AF, Leung RKW, Tan P, Gau G. Plasma catecholamines and neonatal condition after induction of anaesthesia with propofol or thiopentone at caesarean section. Br J Anaesth 1993; 70: 311-6.

8. Abboud TK, Zhu J, Richardson M, Peres Da 
Silva E, Donovan M. Intravenous propofol vs thiamylal-isoflurane for caesarean section: comparative maternal and neonatal effects. Acta Anaesthesiol Scand 1995; 39: 205-9.

9. Dailland P, Cockshott ID, Lirzin JD, Jacquinot P, Jorrot JC, Devery J, Harmey $\mathrm{JL}$, Conseiller C. Intravenous propofol during cesarean section: placental transfer, concentrations in breast milk, and neonatal effects - a preliminary study. Anesthesiology 1989; 71: 827-34.
10. Sanchez-Alcaraz A, Quintana MB, Laguarda M. Placental transfer and neonatal effects of propofol in caesarean section. J Clin Pharm Therap 1998; 23: 19-23.

11. Celleno D, Capogna G, Tomassetti M, Costantino P, Di Feo G, Nisini R. Neurobehavioural effects of propofol on the neonate following elective caesarean section. Br J Anaesth 1989; 62: 649-54. 